\title{
Cutting frequency and cutting height effects on rough fescue and Parry oat grass yields
}

\author{
WALTER D. WILLMS
}

Abstract

A study was made in the Rough Fescue Grasslands of southwestern Alberta to determine the yield response of rough fescue (Festuca scabrella var campestris Rydb.) and Parry oat grass (Danthonia parryi Scribn.) to 5 cutting frequencies and 3 heights over a 3-year period. The same plants were cut either 1, 2, 4, 8, or 16 times over a 16-week period beginning in mid-May, at 16-, 8-, 4-, 2-, or 1-week intervals, respectively, and at heights of either 5, 10, or $15 \mathrm{~cm}$ above ground level. Yield response to cutting treatments differed significantly from the first to the third treatment year. In the first year, rough fescue and Parry oat grass produced most forage when cut at a height of $5 \mathrm{~cm}$ with 1,2 , or 4 cuts. By the third year, rough fescue produced the greatest yields with a single cut after 16 weeks and Parry oat grass produced the greatest yields when cut at 10 or $15 \mathrm{~cm}$ at 8 -week intervals. The data confirm the high sensitivity of rough fescue to grazing while the plant is growing and suggest that the greatest benefit from the Rough Fescue Grasslands may be derived by grazing in fall or winter. Summer grazing favors Parry oatgrass, which is more tolerant than rough fescue, but forage production on the grassland is reduced.

Key Words: grasslands, simulated grazing, clipping, interval, intensity, harvest

Rough fescue (Festuca scabrella var campestris Rydb.) is the dominant climax species of the Rough Fescue Grasslands in southwestern Alberta. Although rough fescue may form nearly pure stands, Parry oat grass (Danthonia parryi Scribn.) is usually found in association with it throughout the region (Johnston and Dormaar 1970) and may dominate on sites having shallow soils (Moss and Campbell 1947, Looman 1969). Both species are tufted with mostly basal leaves and few reproductive tillers; but rough fescue is a large plant with the vegetative portion about $50 \mathrm{~cm}$ in height (Johnston 1961) whereas Parry oat grass is about $20 \mathrm{~cm}$ in height. Rough fescue is deep rooted and, of the native species, is the most productive forage on good condition range in the foothills region. Stout et al. (1981) found that cumulative yield of rough fescue reached a maximum by the end of July.

Grazing affects the relative proportions of each species in the grassland, with light grazing reducing the composition of rough fescue and increasing Parry oat grass (Looman 1969). As a result, Parry oat grass is often the most productive forage species on grazed range (Moss 1955). In one study, grazing reduced the composition of rough fescue from $42 \%$ with no grazing to $38 \%$ with light grazing (1.2 AUM/ha) and $2 \%$ with very heavy grazing ( 4.8 AUM/ha). At the same time, Parry oat grass increased from $19 \%$ of basal area with no grazing to $48 \%$ with heavy grazing $(2.4$ $\mathrm{AUM} / \mathrm{ha}$ ) but decreased to $35 \%$ with very heavy grazing (Willms et al. 1985). The susceptibility of rough fescue to defoliation was demonstrated in a greenhouse study by Johnston (1961) where 20\% defoliation, achieved by cutting individual plants of rough fescue at $12-\mathrm{cm}$ heights every 4 weeks, resulted in a reduction of $48 \%$ root growth and $21 \%$ top growth. Sinton (1980) reported depressed first-year forage yields in a rough fescue ( $F$. hallii Vasey) community following a single harvest at several dates from 8 April to 18

\footnotetext{
Author is range ecologist, Agriculture Canada Research Station, Lethbridge, Alberta T1J 4B1. Contribution 3878941.

Manuscript accepted 2 June 1990.
}

October. McLean and Wikeem (1985) clipped individual plants of rough fescue weekly in single-year treatments for various durations from May to August. They found that the greatest yield decrease occurred when plants were clipped at 5 -cm heights from mid-May to late June and the least when cutting ceased in May. Plant mortality was not affected when the cutting height was $20 \mathrm{~cm}$.

Rough fescue and Parry oat grass are valuable forage species for livestock production and rangeland conservation, and yet no information is available on their response to repeated annual defoliation under specific harvesting regimes. Although single-year treatments can provide useful information on the plant response to grazing, repeated yearly treatments are more realistic because cows tend to regraze plants in consecutive years. Furthermore, the implementation of time-controlled grazing systems allows greater control of livestock distribution, thereby enabling better control of defoliation. As a result, more management options are available, which increases the need for information on plant response to grazing regimes. Therefore, a study was conducted to measure the effects of repeated annual defoliation, in relation to number of cuts during the growing season and cutting heights, on the yield of rough fescue and Parry oat grass.

\section{Materials and Methods}

\section{Site Description}

The study was made in the Porcupine Hills of southwestern Alberta at Stavely, the Agriculture Canada Research Substation about $85 \mathrm{~km}$ northwest of Lethbridge. The vegetation is representative of the Rough Fescue Association described by Moss and Campbell (1947). The soils are classified as Orthic Black Chernozemic (Udic Haploboroll) developed on till overlying sandstone. Annual precipitation data at the substation were not available, but averaged $614 \mathrm{~mm}$ on 2 similar areas within $65 \mathrm{~km}$. However, precipitation over the growing season was below the long-term average in each year of the study (Table 1). The study area was

Table 1. Precipitation during the growing season at the Stavely Substation over the period of study.

\begin{tabular}{lcccccc}
\hline \hline & \multicolumn{6}{c}{ Precipitation (mm) } \\
\cline { 2 - 6 } Total & April & May & June & July & August & \\
\hline 1983 & 30 & 21 & 28 & 57 & 32 & 168 \\
1984 & 23 & 46 & 71 & 27 & 1 & 168 \\
1985 & 20 & 23 & 0 & 31 & 99 & 173 \\
1986 & 11 & 52 & 78 & 77 & 38 & 256 \\
1987 & 22 & 3 & 27 & 63 & 60 & 175 \\
$34-y r$ & & & & & & \\
average & 64 & 70 & 99 & 55 & 60 & 348 \\
\hline
\end{tabular}

located on a southwest slope with less than a $5 \%$ grade. The area had experienced either no grazing or only light fall grazing from 1949 until 1982, when it was fenced to exclude livestock.

\section{Treatments}

The effects of cutting intensity at 5-, 10-, or 15-cm heights (CH5, $\mathrm{CH} 10$, and $\mathrm{CH} 15$, respectively) and cutting frequency, every $\mathrm{l}, 2,4$, 8, or 16 weeks (FR16, FR8, FR4, FR2, and FR1, respectively), 
Table 2. Observed signiffcance levels (OSL) of F ratios indicating the repeatability of yield responses for rough fescue and Parry oat grass in the first and third year of treatment. Also OSL's of differences in yield response between the 2 years.

\begin{tabular}{|c|c|c|c|c|c|c|}
\hline \multirow[b]{2}{*}{ Source } & \multicolumn{3}{|c|}{ Rough fescue } & \multicolumn{3}{|c|}{ Parry oat grass } \\
\hline & lst & 3 rd & Difference & 1st & 3 rd & Difference \\
\hline Cutting frequency $(F)$ & 0.003 & $<0.001$ & 0.006 & 0.400 & 0.105 & 0.384 \\
\hline $\begin{array}{l}\text { linear }(1 F) \\
\text { quadratic }(q F) \\
\text { cubic }(c F) \\
\text { quartic (quF) }\end{array}$ & $\begin{array}{r}0.271 \\
0.784 \\
<0.001 \\
0.012\end{array}$ & $\begin{array}{r}<0.001 \\
0.002 \\
<0.001 \\
0.001\end{array}$ & $\begin{array}{l}0.002 \\
0.012 \\
0.994 \\
0.312\end{array}$ & $\begin{array}{l}0.300 \\
0.785 \\
0.247 \\
0.242\end{array}$ & $\begin{array}{l}0.248 \\
0.399 \\
0.052 \\
0.077\end{array}$ & $\begin{array}{l}0.578 \\
0.376 \\
0.150 \\
0.389\end{array}$ \\
\hline Cutting height $(\mathrm{H})$ & 0.059 & 0.123 & 0.007 & 0.173 & 0.072 & 0.069 \\
\hline $\begin{array}{l}\text { linear }(1 \mathrm{H}) \\
\text { quadratic }(\mathrm{qH})\end{array}$ & $\begin{array}{l}0.025 \\
0.742\end{array}$ & $\begin{array}{l}0.057 \\
0.572\end{array}$ & $\begin{array}{l}0.003 \\
0.995\end{array}$ & $\begin{array}{l}0.092 \\
0.764\end{array}$ & $\begin{array}{l}0.038 \\
0.466\end{array}$ & $\begin{array}{l}0.036 \\
0.545\end{array}$ \\
\hline $\mathbf{F} \times \mathbf{H}$ & 0.038 & 0.269 & 0.041 & 0.110 & 0.379 & 0.255 \\
\hline $\begin{array}{l}1 \mathrm{~F} \times \mathrm{lH} \\
\mathrm{qF} \times 1 \mathrm{H} \\
\mathrm{cF} \times 1 \mathbf{H} \\
\mathrm{qu} F \times \mathrm{IH} \\
\mathrm{l} \mathrm{F} \times \mathrm{qH} \\
\mathrm{qF} \times \mathrm{qH} \\
\mathrm{cF} \times \mathrm{qH} \\
\mathrm{quF} \times \mathrm{qH}\end{array}$ & $\begin{array}{l}0.014 \\
0.957 \\
0.007 \\
0.093 \\
0.461 \\
0.846 \\
0.631 \\
0.354\end{array}$ & $\begin{array}{l}0.301 \\
0.129 \\
0.153 \\
0.308 \\
0.170 \\
0.923 \\
0.671 \\
0.194\end{array}$ & $\begin{array}{l}0.107 \\
0.424 \\
0.004 \\
0.056 \\
0.180 \\
0.836 \\
0.523 \\
0.940\end{array}$ & $\begin{array}{l}0.055 \\
0.859 \\
0.113 \\
0.029 \\
0.384 \\
0.916 \\
0.557 \\
0.107\end{array}$ & $\begin{array}{l}0.111 \\
0.128 \\
0.256 \\
0.408 \\
0.778 \\
0.371 \\
0.453 \\
0.829\end{array}$ & $\begin{array}{l}0.227 \\
0.457 \\
0.283 \\
0.054 \\
0.452 \\
0.530 \\
0.857 \\
0.116\end{array}$ \\
\hline
\end{tabular}

over a 16-week period from 15 May to the end of August were evaluated in a $3 \times 5$ factorial experiment with 10 subsamples and 2 or 3 blocks in a randomized complete block design. The blocks were contiguous to one another and cutting treatments in each block were initiated in different years: for rough fescue, treatments were begun in 3 blocks in either 1983, 1984, or 1985; for Parry oat, treatments were begun in 2 blocks in either 1984 or 1985. Consequently, the blocking factors were site and year. The treatments were repeated over 3 consecutive treatment years on the same plants in each block. The subsampling unit consisted of individual plants of either species, which were systematically selected within belts about 5-m wide by taking the first suitable plants encountered and then randomly partitioning among treatments. Parry oat grass plants were selected within the same belts as rough fescue plants in 1984 and 1985. Plants were considered suitable for selection only if they were clearly defined by purity and boundary.

In the first week of May, in the year that treatments in a block were initiated, all new plants selected were pretreated by cutting to a height of $15 \mathrm{~cm}$ and clearing litter and competing vegetation in a $5-\mathrm{cm}$ wide perimeter from around the base. Cutting at this time removed standing litter but also a small quantity of green herbage from most rough fescue plants. The green herbage was handseparated from the litter and added to the total yield of the plant. The first scheduled cutting was then begun on or about 15 May for FR16, 22 May for FR8, 5 June for FR4, 3 July for FR2, and 28 August for FR1. These dates were adhered to for the initial and repeated treatment of each block. The treatments were applied by cutting plants to the required heights as measured from the ground. Throughout the summer, plants invading within the $5-\mathrm{cm}$ perimeter were removed. All harvested herbage was oven dried and weighed. Annual production was calculated for each plant as the sum of the partial yields at each harvest.

\section{Statistical Analysis}

The effects of cutting frequency and height and their interaction on production were analyzed with a generalized least squares analysis of variance model. Cutting frequency was transformed to a natural log scale and single degree of freedom polynomial contrasts, to the highest possible order, were used to evaluate the trends and their complexity. Yields obtained after 1, 2, or 3 years of repeated treatment from each block were evaluated in a separate analyses. In the analysis, plant area was used as a covariate to adjust yield for plant size. The block effect and its interaction with individual main effects, or their interaction, was the appropriate error term for specific F-ratios. The effect of repeated treatment over time, from the first to third year, was evaluated by subtracting yields in the third year from yields in the first year and testing the differences. Procedures followed Rowell and Walters (1976).

Data for rough fescue and Parry oat grass were analyzed separately as well as in a combined analysis for these years when both were studied. Where the analyses were combined by species, only the variables pertaining to species effects are reported.

Plant growth for each species was measured as the yield taken from plants clipped for the first time at FR16 to FR1 (CH5). Therefore, growth could be determined only in the first year each block was treated.

Regrowth of plants from the FR2 CH5 to 15 treatments was further evaluated because of an apparently large effect of that treatment on total yield. Regrowth from about 3 July to 28 August was compared with growth of previously unclipped plants in the first treatment year and, in another test, regrowth in the first treatment year was compared with regrowth in the third treatment year. In the first test, the 4 treatments ( $d f=3$ ) were growth (1) and regrowth $(2,3,4)$ from $\mathrm{CH} 5$ to 15 and the error term was the interaction of treatment $\times$ block ( $d f=6$ for rough fescue or $\mathrm{df}=3$ for Parry oat grass). The second test was analyzed as a split plot with cutting height $(\mathrm{df}=2$ ) as the main effect and treatment year ( $\mathrm{df}$ $=1$ ) as the secondary effect. In this test, the error term for the main effects was the interaction between treatment year $\times$ block and the error term for the secondary effects, or its interaction with the main effect, was the treatment year $\times$ block $\times$ cutting height interaction (df for both error terms was 4 for rough fescue and 2 for Parry oat grass). A single degree of freedom test was used to compare specific means (Steel and Torrie 1980).

\section{Results}

Yields of rough fescue were greatest with a single harvest near the end of August (Fig. 1) and decreased significantly in a nonlinear trend with increased cutting frequency (Table 2). Cutting height had a significant $(P=0.025)$ linear effect in the first treatment year but no effect $(P>0.05)$ in the third year. A significant interaction of cutting frequency and height was detected in the first treatment year but not in the third year. 

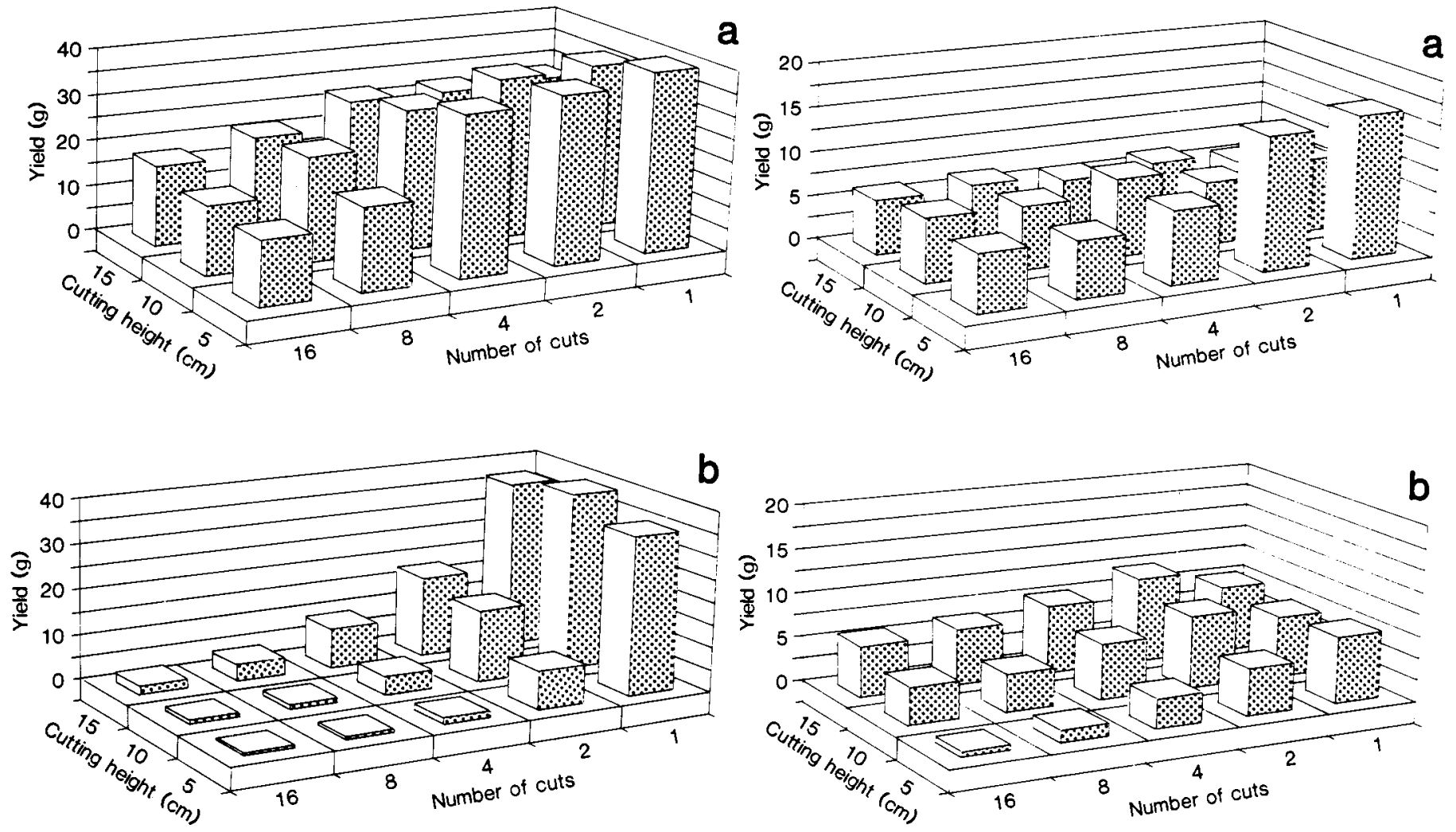

Fig. 1. Average of 3 yield responses of rough fescue to cutting frequency (number of cuts over a 16-week period) and height: a) first-year response, b) third-year response.

Differences in rough fescue yield response from the first to the third year were most noticeable in the mid-frequency ranges of the cutting heights (Table 2). The difference between years 1 and 3 was significant $(P<0.01)$ by cutting frequency and height (Table 2$)$. The second and third year results were similar in response to frequency $(P=0.86)$, height $(P=0.31)$, and the interaction of frequency and height $(P=0.98)$.

In the first year of treatment, Parry oat grass yields were greatest with 1 or 2 cuts during the growing season (Fig. 2a). Neither cutting frequency, cutting height nor their interaction was significant $(P>0.10$, Table 2). By the third year of treatment, greatest dry matter yields were produced with 2 cuts at $15-\mathrm{cm}$ height (Fig. $2 \mathrm{~b}$ ). Both cutting frequency $(P=0.052)$ and cutting height $(P=0.038)$ affected yields but their interaction did not $(P>0.11)$. Cutting height had a significant linear effect $(P=0.036)$ on the yield response from the first to the third year of treatment (Table 2) but cutting frequency and its interaction with height had no effect. The second and third year results were similar in response to frequency $(P=0.86)$, height $(P=0.31)$, and the interaction of frequency and height $(P=0.98)$.

Rough fescue and Parry oat grass responded similarly to cutting frequency $(P=0.12)$, cutting height $(P=0.80)$, and the interaction of frequency and height $(P=0.59)$ in the first year of treatment. However, by the third year of treatment, the yield response of rough fescue and Parry oat grass to frequency was different $[(P=$ 0.001 ), Figs. $1 \mathrm{~b}$ and $2 \mathrm{~b}$ ], whereas their response to cutting height and its interaction with frequency was similar $(P>0.67)$.

Average forage yields of plants ( $\mathrm{g} \pm 1 \mathrm{SEM}$ ) cut at $5-\mathrm{cm}$ height, in the first treatment year, for the first time on or about 15 May (FR16), 22 May (FR8), 5 June (FR4), 3 July (FR2), and 28 August (F1) were, respectively, 9.7 (0.95), 12.6 (1.22), 27.4 (2.83), 35.7

Fig. 2. A verage of 2 yield responses of Parry oat grass to cutting frequency (number of cuts over a 16-week period) and height: a) first-year response, b) third-year response.

(2.87), and 50.7 (3.60) for rough fescue in 3 blocks, and $1.8(0.34)$, $2.6(0.36), 3.8(0.28), 7.4(0.76)$, and $11.9(1.40)$ for Parry oat grass in 2 blocks. Thus, growth for the period from 3 July to 28 August of previously untreated plants was $15.0(28 \%)$ and $4.6 \mathrm{~g}(39 \%)$ for rough fescue and Parry oat grass, respectively (Table 4 ).

Table 3. Average change in yield response of rough fescue due to cutting frequency (number of cuts over 16-week period) and height with repeated treatment over 3 years (observed significance levels for tests of specific trends are reported in Table 2).

\begin{tabular}{ccrccc}
\hline \hline \multirow{2}{*}{$\begin{array}{c}\text { Cutting height } \\
(\mathrm{cm})\end{array}$} & 1 & 2 & 4 & 8 & 16 \\
\hline 5 & 13.2 & 28.7 & 33.9 & 17.7 & 13.8 \\
10 & -3.1 & 19.4 & 26.5 & 21.7 & 14.3 \\
15 & -8.9 & 9.4 & 18.1 & 17.5 & 15.5 \\
\hline
\end{tabular}

Regrowth from 3 July to 28 August over all cutting heights, in the first year of treatment of rough fescue and Parry oat grass plants, was significantly less than growth for the same period (Table 4). As a proportion of total yield, regrowth of rough fescue was less while Parry oat grass was similar.

Plant mortality, defined as zero live tillers within a plant, by treatment after the first/second years of cutting, for rough fescue was: FR $16 \mathrm{CH} 5,23 / 37 \%$, FR 8 CH5, $20 / 33 \%$, FR 4 CH5, $03 \%$; FR $16 \mathrm{CH} 10,3 / 3 \%$; FR8 CH $10,33 \%$; FR $4 \mathrm{CH} 10,3.3 \%$; and FR 4 $\mathrm{CH} 15,0 / 3 \%$. Parry oat grass experienced no mortality after the first year and 5\% mortality in treatments FR $16 \mathrm{CH} 5, \mathrm{FR} 16 \mathrm{CH} 10$, and FR8 CH10 after the second year. There was no plant mortal- 
Table 4. Comparison of plant growth, during the period July through August, with regrowth for the same period of plants (F2 CH5 to 15) harvested once on 3 July in the first year of treatment or following repeated harvests on 3 July and 28 August in the third year of treatment.

\begin{tabular}{|c|c|c|c|c|}
\hline & \multicolumn{2}{|c|}{ Rough fescue } & \multicolumn{2}{|c|}{ Parry oat grass } \\
\hline & $\mathrm{g} /$ plant & Proportion $^{1}$ & g/plant & Proportion $^{1}$ \\
\hline Growth (1) & 15.03 & 0.279 & 4.62 & 0.388 \\
\hline \multicolumn{5}{|l|}{ First year } \\
\hline $\begin{array}{l}\text { CH5 (2) } \\
\text { CH10 (3) } \\
\text { CH15 (4) }\end{array}$ & $\begin{array}{l}3.49 \\
4.78 \\
4.47\end{array}$ & $\begin{array}{l}0.081 \\
0.113 \\
0.151\end{array}$ & $\begin{array}{l}3.74 \\
2.80 \\
2.52\end{array}$ & $\begin{array}{l}0.310 \\
0.357 \\
0.351\end{array}$ \\
\hline \multicolumn{5}{|l|}{ Third year } \\
\hline $\begin{array}{l}\text { CH5 (5) } \\
\text { CH10 (6) } \\
\text { CH15 (7) }\end{array}$ & $\begin{array}{l}1.87 \\
3.53 \\
4.09\end{array}$ & $\begin{array}{l}0.215 \\
0.208 \\
0.236\end{array}$ & $\begin{array}{l}1.82 \\
2.75 \\
3.72\end{array}$ & $\begin{array}{l}0.416 \\
0.422 \\
0.456\end{array}$ \\
\hline
\end{tabular}

Contrasts ${ }^{2}$

$\begin{array}{lllll}1 \text { vs } 2,3,4 & 0.034 & 0.004 & 0.013 & 0.111 \\ 1 \text { vs } 2 & 0.054 & 0.002 & 0.100 & 0.102 \\ 1 \text { vs } 3 & 0.078 & 0.011 & 0.016 & 0.196 \\ 1 \text { vs } 4 & 0.071 & 0.060 & 0.011 & 0.228 \\ 2,3,4, \text { vs } 5,6,7 & 0.040 & 0.002 & 0.615 & 0.071\end{array}$

I Proportion of growth or regrowth, from about 3 July to 28 August, to total annual yield.

2Probabilities that means are equal.
${ }_{2}$.

ity in other treatments.

Reproductive culms became noticeable in rough fescue by midMay, flowering occurred by June, and seeds had ripened by midJuly. Parry oat grass flowered about 4 weeks later.

\section{Discussion}

Rough fescue was highly susceptible to defoliation during the growing season regardless of the cutting frequency or height. While plant mortality was not a factor with fewer cuts (FR2 or FR4), plant yield was significantly reduced from that of a single harvest after the growing season (FR1).

Rough fescue mortality after 3 years of repeated cutting was considerably less than that reported by McLean and Wikeem (1985), who found an average mortality of $92 \%$ after the first year among plants cut at about the severity level of FR 16 CH5. The high mortality may be partly due to competing vegetation which was left in place instead of being removed as in this study. A few surviving tillers are significant for the recovery of overgrazed Rough Fescue Grasslands because they provide the basis for regeneration; heavily grazed plants do not produce seed.

Rough fescue yields at a moderate cutting frequency (FR2 and FR4) were not reduced until after the first year, thereby demonstrating the need for at least 2 years of repeated treatment when assessing plant response. The severe response to a single cut in July may be due to reduced carbohydrate reserves found in some grasses prior to seed formation (Smith 1972). Although carbohydrates were not analyzed, and their significance to regrowth is questionable (Caldwell et al. 1981, Richards 1986), McLean and Wikeem (1985) suggest that depressed vigor in response to weekly cuts from May to July was the result of reduced regrowth potential due to lower carbohydrate reserves. Caldwell et al. (1981) believed that regrowth potential was less related to carbohydrate reserves than to species potential.

While rough fescue decreases with overgrazing, Parry oat grass increases with a corresponding decrease in forage yield (Willms et al. 1985, 1986b). This trend was also demonstrated in the present study, which showed that Parry oat grass was less productive than rough fescue but also less affected by cutting frequency or height.
Although the severe cutting treatments resulted in the death of some plants and a substantial reduction in yield of the survivors, by the third treatment year the moderate cutting treatments enhanced yields and, presumably, plant vigor.

The July cutting (FR2) appeared critical for either reducing yields in rough fescue or increasing yields in Parry oat grass in comparison with those from a single harvest (F1). Regrowth in both rough fescue and Parry oat grass was impaired after cutting in the first year but, while rough fescue regrowth averaged $28.3 \%$ $(4.25 \mathrm{~g})$ of growth, regrowth of Parry oat grass averaged $65.3 \%$ $(3.02 \mathrm{~g})$ (Table 4).

The continued reduction of regrowth to the third year appears to be at least partly caused by a year effect, perhaps interacting with litter removal, since the FR1 yields were also less than in the first treatment year when litter was first removed (Table 3). Litter is important in conserving water and enhancing yields in waterlimiting environments (Willms et al. 1986a), which likely persisted over the duration of the study (Table 1). Although repeated annual cutting in late August only may have reduced yields, this possibility appears remote, particularly with Parry oat grass, which produced the greatest yields with 2 cuts (Fig. 2b).

The relative susceptibilities of rough fescue and Parry oat grass to grazing have long been recognized. However, the nature of that response was not clear. This study demonstrated that Parry oat grass can withstand frequent but less intense defoliation, and rough fescue can not. This leads to the conclusion that the Rough Fescue Grasslands are managed most efficiently with a single defoliation at the end of the growing season or, in practice, by extending the grazing season into fall or winter.

The contrasting responses of the 2 species to grazing present constraints or opportunities for their management. For the Rough Fescue Grasslands to yield the greatest sustained quantity of forage, they must be grazed after the growing season in order to maintain them in a healthy state. Grazing systems that do not incorporate dormant-season grazing are unlikely to prevent the decline of rough fescue in the grassland. Overgrazing will severely reduce rough fescue and recovery may require more than 30 years (Willms et al. 1985). Season-long moderate or light grazing pressure may not be desirable because it results in overgrazed and undergrazed patches (Willms et al. 1988) with a net effect of reduced grazing efficiency. On the other hand, heavy sustained grazing pressure will eliminate grazed patches and produce more beef per unit area (Willms et al. 1986b) but mostly from Parry oat grass. Therefore, without considering subsequent effects on the soil, grazing recommendations to produce maximum beef would be to manage for either Parry oat grass under summer grazing or for rough fescue under fall and winter grazing. The former recommendation is not desirable because the soils may deteriorate (Johnston et al. 1971) and watershed properties weaken (Naeth 1988).

The present study did not examine all possible strategies for grazing during the growing season nor did it evaluate the cost of delayed grazing in terms of weathering losses of dry matter, nutrients, and animal performance. More work needs to be done in order to provide a more complete analysis. The choices presented to the grazing manager are: to sacrifice rough fescue in order to maximize beef production; to graze inefficiently at low or moderate stocking rates that result in overgrazed or undergrazed patches; or to delay grazing until after the growing season and sustain maximum productivity.

\section{Literature Cited}

Caldwell, M.M., J.H. Richards, D.A. Johnson, R.S. Nowak, and R.S. Dzurec. 1981. Coping with herbivory: photosynthetic capacity and resource allocation in two semiarid Agropyron bunchgrasses. Oecologia (Berl) 50:14-24. 
Johnston, A.1961. Comparison of lightly grazed and ungrazed range in the fescue grassland of southwestern Alberta. Can. J. Plant Sci. 41:615-622.

Johnston, A., and J.F. Dormasr. 1970. Observations on Danthonia parryi. Can. J. Plant Sci. 50:115-117.

Johnston, A., J.F. Dormaar, and S. Smoliak. 1971. Long-term grazing effects on fescue grassland soils. J. Range Manage. 24:185-188.

Looman, J. 1969. The fescue grasslands of Western Canada. Vegetatio 19:128-145.

McLean, A., and S. Wikeem. 1985. Rough fescue response to season and intensity of defoliation. J. Range Manage. 38:100-103.

Moss, E.H. 1955. The vegetation of Alberta. Bot. Rev. 21:493-567.

Moss, E.H., and J.A. Campbell. 1947. The fescue grasslands of Alberta. Can. J. Res. 25:209-227.

Naeth, M.A. 1988. The impact of grazing on litter and hydrology in Mixed Prairie and Fescue Grassland ecosystems of Alberta. PhD. Thesis, Univ. of Alberta, Edmonton.

Richards, J.H. 1986. Plant response to grazing: the role of photosynthetic capacity and stored carbon reserves, p. 428-430. In: Rangelands: A resource under siege. Proc. 2nd Internat. Rangelands. Congr., Cambridge Univ. Press, Sydney.

Rowell, J.G., and D.E. Walters. 1976. Analyzing data with repeated observations on each experimental unit. J. Agr. Sci. 87:423-432.
Sinton, H.M.M. 1980. Effect of burning and mowing on Festuca hallii (Vasey) Piper, Festuca scabrella Torr. M.Sc. Thesis, Univ. of Alberta, Edmonton.

Smith, D. 1972. Carbohydrate reserves of grasses, p. 318-333. In: Youngner, V.B. and C.M. McKell (eds.). The biology and utilization of grasses. Academic Press, New York.

Steel, R.G.D., and J.H. Torrie. 1980. Principles and procedures of statistics: a biometrical approach. 2nd ed. McGraw-Hill Book Co., New York. Stout, D.G., A. McLean, and D.E. Quinton. 1981. Growth and phenological development of rough fescue in the interior of British Columbia. $J$. Range Manage. 34:455-459.

Willms, W.D., J.F. Dormaar, and G.B. Schaalje. 1988. Stability of grazed patches on rough fescue grasslands. J. Range Manage. 41:503-508.

Willms, W.D., S. Smoliak, and A.W. Bailey. 1986a. Herbage production following litter removal on Alberta native grasslands. J. Range Manage. 39:536-540.

Wilms, W.D., S. Smoliak, and J.F. Dormaar. 1985. Effects of stocking rate on rough fescue grassland vegetation. J. Range Manage. 38:220-225.

Willms, W.D., S. Smoliak, and G.B. Schaalje. 1986b. Catle weight gains in relation to stocking rate on Rough Fescue Grassland. J. Range Manage. 39:182-186. 